\title{
Legal Protection on Sinking Victims of KM. Sinar Bangun Ship at Toba Lake in the Criminal Law Perspective
}

\author{
Riswan Munthe ${ }^{1}$, Sri Hidayani ${ }^{2}$ \\ ${ }^{1,2}$ Faculty of Law, Universitas Medan Area, Medan, Indonesia \\ riswan@staff.uma.ac.id
}

\begin{abstract}
This research deals with legal protection on sinking victims Of Km Sinar Bangun Ship at Toba Lake in the criminal law perspective. This type of research used in this study is in the form of qualitative research with an empirical juridical research approach. The result shows that the form of legal protection given to the victims sinking of KM. Sinar Bangun in Toba Lake is that every accident victim is entitled to protection based on the provisions of the legislation, which is provided by the government in the form of direct social assistance in the form of cash through the Ministry of Social Affairs, types of compensation for victims in the form of death compensation, permanent disability compensation, and survivors. Each accident victim also received compensation from PT Jasa Raharja (Persero), the amount of which was determined by the miniser of finance, in addition to other legal protections the implementation of legal proceedings for the occurrence of criminal acts.
\end{abstract}

Keywords legal protection; victims, KM Sinar Bangun Ship, criminal law

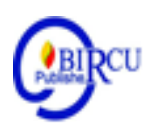

\section{Introduction}

Carrying out transportation is a reciprocal agreement between the service of the carrier and the passenger, whereby the carrier is bound to carry out the transportation of goods and / or people safely from a certain place to a destination, while the passenger or sender is bound to pay the transportation fee.

Motor Ship Accident on Monday, June 18, there was a sinking of KM Sinar Bangun 4 GT.35 No. 177 in Toba Lake waters +1 (one) Mile from the Port of Simanindo, Samosir Regency headed to Port of Tiga Ras Nagori Dolok Pardamean Sub-district Simalungun Regency, North Sumatra Province which was originally the KM. Sinar Bangun Ship 4 GT.35 No. 117 departs from the port of Simanindo Samosir Regency headed to Port of Tiga Ras, Simalungun Regency around 16.50 p.m by carrying around 180 passengers and also carrying the motorcycles of approximately 70 units.

The tragedy of KM. Sinar Bangun on Toba Lake leaves a big question mark about safety guarantees in ferry transportation. The lack of supervision of crossing transportation on Toba Lake caused 3 (three) victims died, and 184 people lost their lives due to the sinking of KM. Sinar Bangun which is overloaded. A week after the incident, the North Sumatra Regional Police set 4 (four) initial suspects in this case. Not only the owner of the ship, but the police also prosecuted a number of transportation service officials responsible for the incident. They are Poltak Soritua Sagala as the owner and captain of KM. Sinar Bangun, an honorary member of the Simanindo Port Post named Karnilan Sitanggang, became a suspect considering that his job was supposed to regulate the entry of passengers and oversee ship activities and shipping. He should have banned overloading ships and prohibited sailing if it 
was not feasible. In addition, there has also been a warning of bad weather from BMKG, but the fact is that the person concerned is not doing his job properly. So Golpa F. Putra, who is the Head of Simanindo Port Post, is considered to have left his duties but still charges retribution. The other suspect was Head of Samosir Regency River and Lake Water Transport Section, Rihad Sitanggang, considered failing to supervise port activities in Samosir, even though he was responsible. In reality he, among other things, still allowed traditional vessels to carry motorcycles, which were prohibited, and allowed ships to over capacity or sail without a permit.

Here is a picture at the time of incident of KM. Sinar Bangun when sinking:

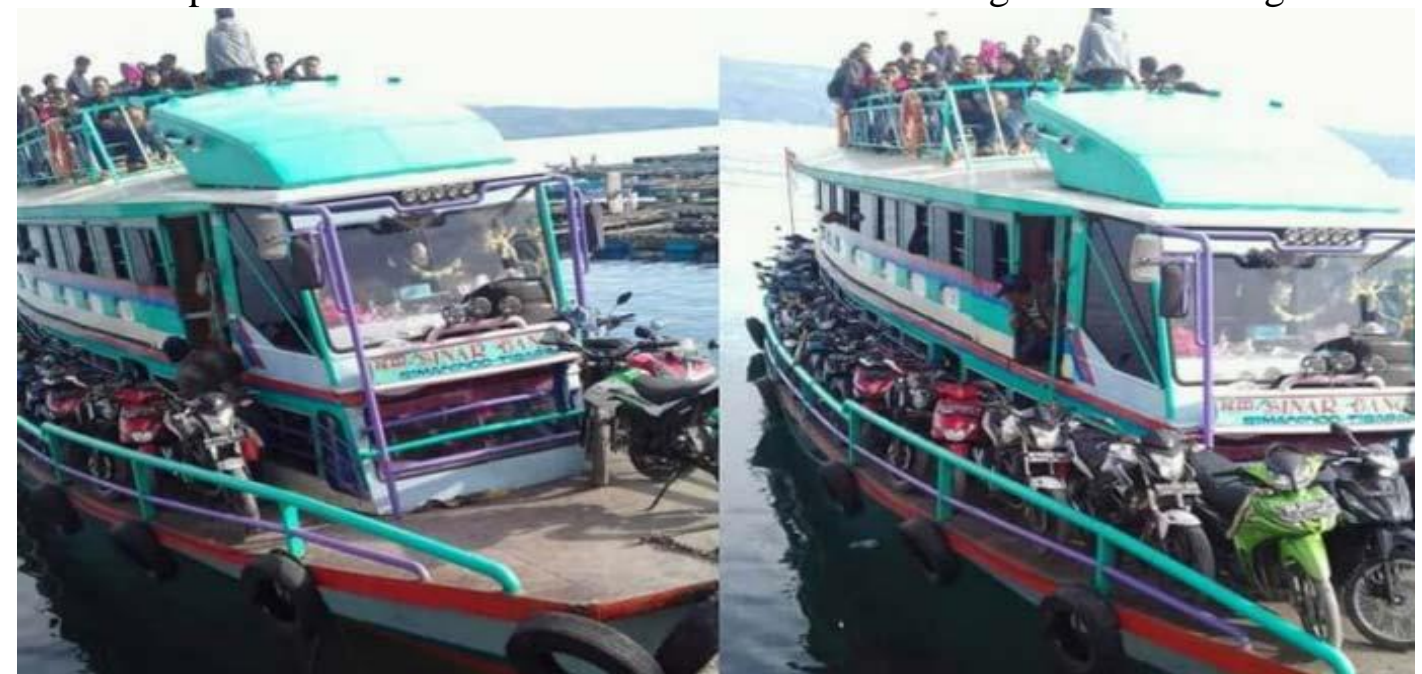

Figure 1. Before the Sinar Bangun Ship departed

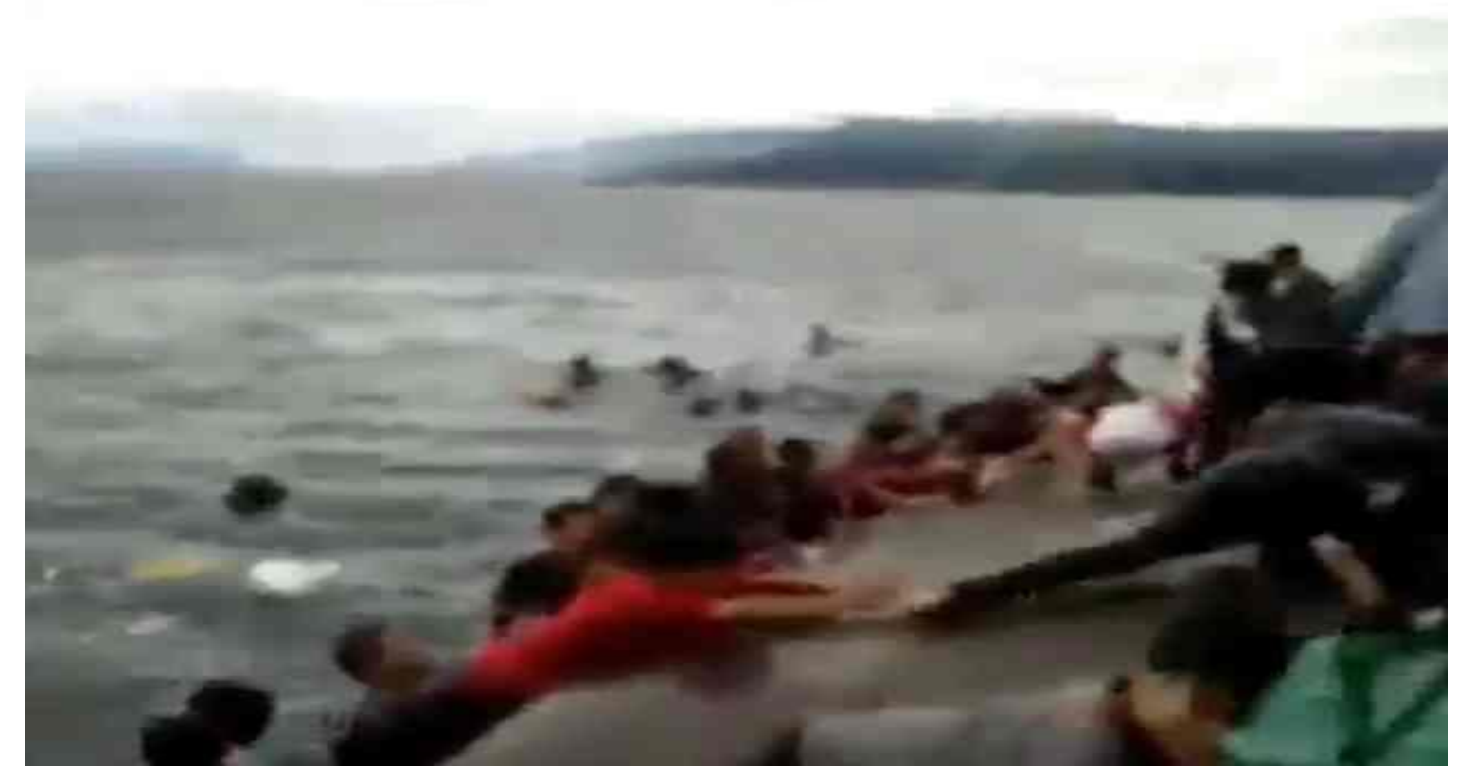

Figure 2. The condition of the Sinar Bangun Ship when sinking, passengers try to save themselves 


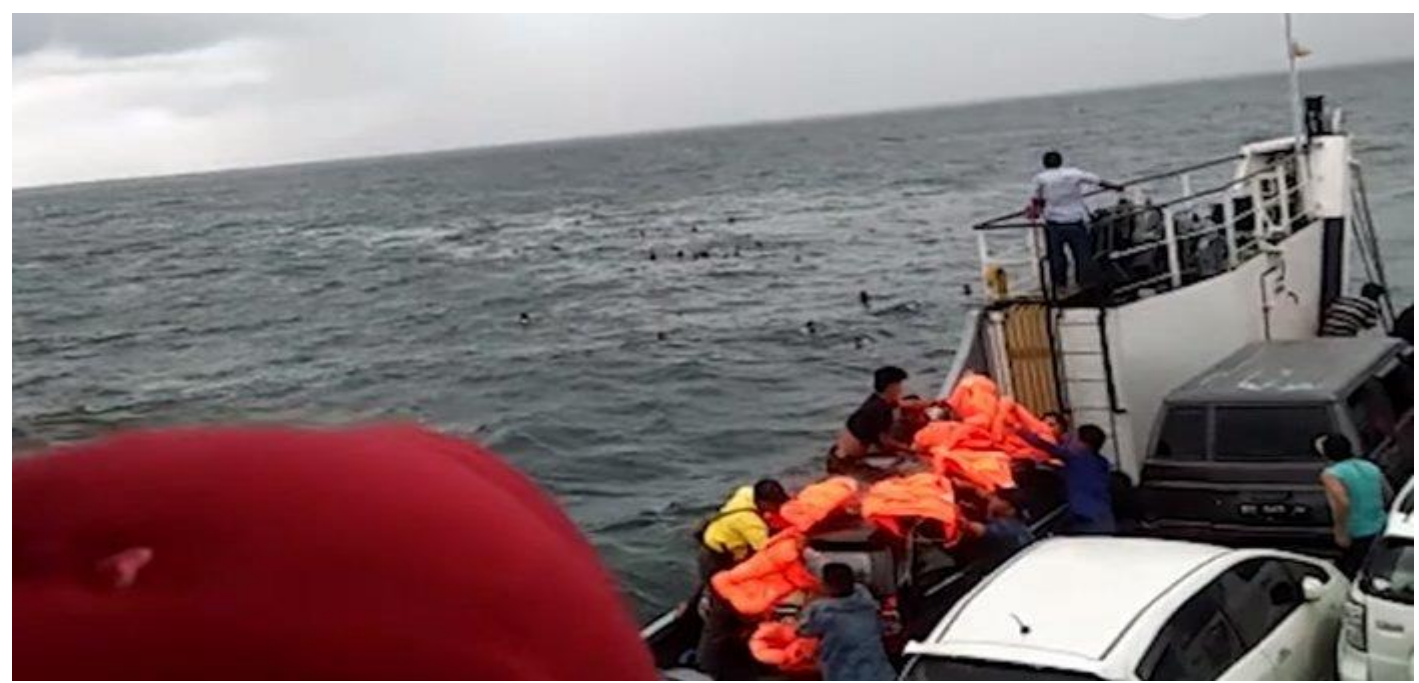

Figure 3. A passing ship provides assistance to victims who are trying to save themselves

184 Passenger of KM. Sinar Bangun is missing, the mode of the perpetrators determined as the party responsible for the incident is seeking profit by loading passengers beyond the capacity of KM. Sinar Bangun which is only 45 people. But the estimated number of passengers reached more than 188 people. That number does not include dozens of motorcycles that were also deliberately transported to the special ferry passenger ship. As a result, after a few minutes of sailing, the ship's engine died, while the ship tilted to the right and turned upside down.

\section{Review of Literature}

\subsection{The Definition of Legal Protection}

The presence of law is nothing but the protection of human interests in the form of norms or methods. The law as a collection of rules or methods contains content that is general and normative, general because it applies to everyone, and normative because it determines what is and is not permissible, and determines how to implement compliance with the method. (Sudikno Mertokusumo, 2003: 39)

Based on Article 1 number 8 of Law Number 31 Year 2014 Amendment to Law Number 13 of 2006 concerning Protection of Witnesses and Victims, which reads "protection is all efforts to fulfill rights and provide assistance to provide a sense of security to witnesses and / or victims who must be carried out by LPSK or other institutions in accordance with the provisions of this law. " Legal protection for the community is very important because the community, both groups and individuals, can be victims and even as perpetrators of crime.

The aim of legal protection is expected to obtain real justice or responsive, accommodating justice for comprehensive legal interests, both from the criminal aspect as well as from the civil and administrative aspects, therefore to achieve responsive justice it is necessary to have legal awareness from all walks of life including government agencies and the public to obey the law itself.

\subsection{The Definition of Victim}

Regarding the understanding of the victims themselves listed in Article 1 number 3 of Law Number 31 of 2014 Amendment of Law Number 13 of 2006 concerning Protection of 
Witnesses and Victims which states that the victim is a person who suffers physical, mental, and / or economic loss caused by a crime. According to Arif Gosita, what was meant by the victim was:

Those who suffer physically and spiritually as a result of the actions of others who are contrary to their own interests or others who seek the fulfillment of their own interests or others who are contrary to the interests of suffering human rights. (Rena Yulia, 2010: 49)

\subsection{Victims' Rights}

As a party that suffers suffering and loss of course the victim has rights that can be obtained as a victim. The rights of the victims according to Van Boven are the right to know, the right to justice and the right to reparation (recovery), which is the right that refers to the type of recovery both material and non-material for victims of human rights violations. These rights have been found in various applicable human rights instruments and also in the jurisprudence of international human rights committees and regional human rights courts. (Rena Yulia, 2010: 55)

In many cases, there are problems when victims provide information in the judicial process, which is caused by interruption, forcing victims to provide information in unusual and unnatural ways, and giving questions that produce short answers. A judicial process based on the concentration of victims should provide space for victims to construct their narratives in full. However, this does not mean that victims are permitted to threaten the perpetrators, witnesses of the perpetrators, and the like. That is, there will still be certain limitations even though the system is based on the concentration of victims.

\subsection{The Definition of Criminal Law}

Criminal law is the most difficult part of the law. Because criminal law has many aspects, each of which has its own meaning. Where, the scope of criminal law is broad and can also be narrow. A law is a part of the entire law in force in a country, which establishes the basis and rules for:

a. Determine which actions should not be carried out, which are prohibited, accompanied by threats or sanctions, in the form of certain penalties for those who violate the prohibition.

b. Determine when and in what ways those who violate the restrictions can be imposed or convicted as threatened.

c. Determine how criminal imposition can be carried out if there is a person suspected of having violated the prohibition. (Jur. Andi Hamzah, 2012: 4-5)

\section{Research Method}

In accordance with the title of the research and the problems raised in this study, the implementation will be carried out in the North Sumatra Regional Police because the investigator in the incident was the North Sumatra Regional Police and possibly also conducted in Simanindo Sub-district, Samosir Regency.

This type of research used in this study is in the form of qualitative research with an empirical juridical research approach. The empirical juridical research method is a legal 
research conducted by examining directly to the field where the object under study in the North Sumatra Regional Police and in Simanindo Sub-district, Samosir Regency.

\section{Discussion}

Legal protection is an illustration of the operation of the legal function to realize legal objectives, namely benefits, certainty and legal justice. Legal protection is a protection that gives legal subjects in accordance with the rule of law, both preventive and repressive, in writing or unwritten in the context of enforcing regulations. Basically everyone has the right to get legal protection, because the form of protection will be divided into two parts, namely direct legal protection and indirect legal protection.

\subsection{Direct Legal Protection}

Direct legal protection is a form of legal protection for victims that is collective in nature including the interests of many people, including improving the consequences of physical and psychological recovery of victims. The forms of direct victim protection include:

a. Compensation for victims

Protection of victims, especially victims' rights to obtain compensation is an integral part of human rights in the field of welfare and social security. Compensation for victims is one form of direct legal protection in accordance with Law Number 31 of 2014 concerning Witness and Victim Protection, which is more explained in compensation to victims in Government Regulation Number 7 of 2017 concerning Granting of Compensation, Restitution, and Assistance to Witnesses and Victims.

\section{b. Provision of restitution to victims}

When viewed from the witness and victim protection law, restitution is contained in Article 7A which states that the LPSK is an authorized body as an intermediary between the victim and the court in applying for restitution. Submission is submitted before and after the decision has a permanent law and certainly has a process that has been regulated in this law. (Maya Indah, 2014: 137)

Whereas in Government Regulation No. 7 of 2018 concerning Provision of Compensation, Restitution and Legal Aid to Witnesses and Victims, as stipulated in Chapter II, the second part, Article 19 to Article 36 which explains how the restitution is submitted in the same way as the witness protection law and victims namely LPSK who played a role in handling granting restitution.

c. Giving compensation to the victims

Giving compensation is not found in the law specifically, but the law on witness and victim protection which in Article 7 of this law, victims of crime are entitled to compensation paid to the human rights court through LPSK, and then LPSK will provide compensation, restitution and assistance the law for Witnesses and Victims, the compensation is explained in chapter II part one contained in Article 2 through Article 18.

d. The rights of other victims to obtain legal protection

Legal protection in this matter is not only material but also immaterial in which victims of a legal event are also entitled to: 
1) Obtain protection for personal, family and property security, and be free from threats relating to the testimony that will be, is, or has been given.

2) Participate in the selection process and determine the forms of protection and security support, provide information without pressure, get translators, free from entrapment questions.

3) Get information about the progress of the case, get information about the court's decision, get information in case the convict is released, withheld his identity.

4) Get a new identity, get a temporary residence, get a new residence, get reimbursed transportation costs as needed.

5) Get legal advice, get temporary living expenses and get assistance.

\subsection{Indirect Protection}

Ships are ships with propulsion used for trading to transport goods, passengers weighing more than 500 tons. Arrangement and management of transportation of goods transporting and transportation of people has been regulated in Act Number 17 of 2008 concerning Shipping. The forms of regulation in the law cover all aspects including shipping safety, the shape or size of the ship and some requirements that must be met by the company and / or the ship as well as the crew or vessel crews. In the writings of various shipping accidents, transportation of people is generally caused by human error both on land and during sailing, and also caused by companies or ship owners. Many ships carrying people have a design that does not consider aspects of passenger safety, one example is the sinking incident of KM Sinar Bangun 4 on Toba Lake which resulted in hundreds of passengers drowning. In general the victims could not swim and the ship's safety equipment was inadequate so that the passengers were unable to save themselves when an accident occurred. Then the design of the ship that is operated to transport people from the Port of Simanindo Samosir Island to Tiga Ras port, North Sumatra Island, ignores passenger safety aspects.

Based on data obtained that the total number of KM. Sinar Bangun passengers which sank in the waters of Toba Lake based on the following table:

Table 1. Victims of KM Sinar Bangun who survived

\begin{tabular}{|c|l|c|l|}
\hline No & \multicolumn{1}{|c|}{ Name } & Aged & \multicolumn{1}{|c|}{ Address } \\
\hline 1 & Rahman Saputra & 22 & Indrapura \\
\hline 2 & Sri Santika & 26 & Kuala Tanjung \\
\hline 3 & Hernando Lingga & 24 & Tj. Morawa \\
\hline 4 & Riko Sijabat & 26 & Kota Pinang \\
\hline 5 & Tiambuns Situmorang & 16 & Aek Kanopan \\
\hline 6 & Hermanto Turnip & 27 & Tigaras \\
\hline 7 & Suhendra & 22 & P. Siantar \\
\hline 8 & Sandri Sianturi & 23 & Lubuk Pakam \\
\hline 9 & Dedi Setiawan & 22 & Lubuk Pakam \\
\hline 10 & Hafni & 29 & P. Siantar \\
\hline 11 & Toni & 29 & Kota Pinang \\
\hline 12 & Roni & 17 & Simpang Raja Huta \\
\hline 13 & Muh. Riadi Saputra & 23 & Indrapura \\
\hline 14 & Rudi Wibowo & 22 & Binjai \\
\hline 15 & Muhammad Fitri & 21 & Indrapura \\
\hline 16 & Heri Nainggolan & 23 & Panitonga \\
\hline
\end{tabular}




\begin{tabular}{|c|l|c|l|}
\hline 17 & Jamuda & 17 & Parbunga-bunga \\
\hline 18 & Juita Morga & 30 & Serbelawan \\
\hline 19 & Josua Sinaga & 18 & Simpang Raja Huta \\
\hline 20 & Fernando & 27 & Kec. Simanindo \\
\hline 21 & Poltak Saritua Sagala & 43 & Kec. Simanindo \\
\hline \multicolumn{2}{|l}{ Total survivors } & 21 people \\
\hline
\end{tabular}

Data of victims as many as 21 (twenty one) people, in accordance with data obtained by Basarnas from the Tiga Ras Health Center, Department of Communication and Information Samosir Regency and Institution verification results related to Samosir Regional Police, Simalungun Regional Police, Jasa Raharja, Ministry of Transportation, UPTD Region II of North Sumatra, Simalungun Regency, Simalungun Transportation Office, Head of the SAR office in Medan (SMC).

Table 2. KM Sinar Bangun Victims Died

\begin{tabular}{|c|l|c|l|}
\hline No & \multicolumn{1}{|c|}{ Name } & Aged & \multicolumn{1}{c|}{ Address } \\
\hline 1 & Indah Jwita Saragih & 22 & Sidamanik \\
\hline 2 & Fahrianti & 47 & Binjai Selatan \\
\hline 3 & Tri Suci Wulandari & 24 & Aceh Tamiang \\
\hline \multicolumn{2}{|c|}{ Total number of deaths } & & 3 people \\
\hline
\end{tabular}

Data that victims died as many as 3 (three) people, namely 1 (one) person obtained data from the Tiga Ras Health Center and 2 (two) victims who died obtained from the results of a search operation on Wednesday, July 20, 2018 around the waters of Toba Lake.

Table 3. The Victims of the KM. Sinar Bangun missing were found

\begin{tabular}{|c|c|c|c|}
\hline No & Name & Aged & Address \\
\hline 1 & Resmi Sinaga & 60 & $\begin{array}{l}\text { Perasmian Kec. Dolok Sialau Kab. } \\
\text { Simalungun }\end{array}$ \\
\hline 2 & Khayrani Uandayani & 22 & $\begin{array}{l}\text { Warga Medan Jln. SM Raja Gg. } \\
\text { Mandailing }\end{array}$ \\
\hline 3 & Inksan Zulkarnaen & 51 & Warga Deli Tua Medan \\
\hline 4 & Bayu & 30 & Deli Tua Pasar 9 Medan \\
\hline 5 & Nony Zoya & 27 & Warga Medan Titi Kuning \\
\hline 6 & Ferry Sembiring & 31 & Warga Brastagi \\
\hline 7 & Novia Barus & 16 & Warga Medan Marindal \\
\hline 8 & Pandi & 26 & Wargaa Medan Deli Tua Gg. Santria \\
\hline 9 & Jandur Simarmata & 41 & Desa Sihusapi Kec. Simanindo \\
\hline 10 & Tiar Silaban & 32 & Desa Sihusapi Kec. Simanindo \\
\hline 11 & Ami Elisabet & 32 & Desa Sihusapi Kec. Simanindo \\
\hline 12 & Gresia & 11 & Desa Sihusapi Kec. Simanindo \\
\hline 13 & Berliana Si & 50 & \\
\hline 14 & Damersis Purba Tambak & 43 & $\begin{array}{l}\text { Simpang Baga Saribu Dolok Kab. } \\
\text { Simalungun }\end{array}$ \\
\hline 15 & Hotman Manik & 43 & $\begin{array}{l}\text { Warga Sidamanik Parmahanan Kab. } \\
\text { Simalungun }\end{array}$ \\
\hline
\end{tabular}




\begin{tabular}{|c|c|c|c|}
\hline 16 & Hotman Nainggolan & 21 & Warga Sionggang P. Siantar \\
\hline 17 & Dorman Nainggolan & 40 & Warga Sionggang P. Siantar \\
\hline 18 & Ledikson Nainggolan & 38 & Warga Sionggang P. Siantar \\
\hline 19 & Basaria Br. Nainggolan & 35 & Warga Sionggang P. Siantar \\
\hline 20 & Bungaran Nainggolan & 28 & Warga Sionggang P. Siantar \\
\hline 21 & Lilis Lubis & 50 & Warga Sionggang P. Siantar \\
\hline 22 & Hasiholan Sidabutar & 62 & Warga Sionggang P. Siantar \\
\hline 23 & Riani Nainggolan & 50 & Warga Sionggang P. Siantar \\
\hline 24 & Jon Veldi Nainggolan & 8 & Warga Sionggang P. Siantar \\
\hline 25 & Nicolas Nainggolan & 17 & Warga Sionggang P. Siantar \\
\hline 26 & Astrit Nainggolan & 18 & Warga Sionggang P. Siantar \\
\hline 27 & Melinton Togatorop & 26 & Warga Sionggang P. Siantar \\
\hline 28 & Jaya Sidauruk & 21 & Desa Simanindo Kab. Samosir \\
\hline 29 & Jomelin Andreas Purba & 34 & Warga Purba Saribu Haranggaol \\
\hline 30 & Nova Sulastri Sijabat & 21 & $\begin{array}{l}\text { Naga Pane Tiga Runggu Kab. } \\
\text { Simalungun }\end{array}$ \\
\hline 31 & Hotbin Sitanggang & 40 & $\begin{array}{l}\text { Laras Dua Kec. Siantar Kab. } \\
\text { Simalungun }\end{array}$ \\
\hline 32 & Farel Sitanggang & 11 & $\begin{array}{l}\text { Laras Dua Kec. Siantar Kab. } \\
\text { Simalungun }\end{array}$ \\
\hline 33 & Pardamean Purba & 42 & \\
\hline 34 & Bongbong Simarmata & 35 & Nagori Bayu \\
\hline 35 & Jonner Silalahi & & Nagori Bayu \\
\hline 36 & Ader Nainggolan & 48 & Kab. Simalungun \\
\hline 37 & Lonser Nainggolan & 50 & Tiga Runggu Kab. Simalungun \\
\hline 38 & Selma Sinaga & 25 & Tiga Ras Kab. Simalungun \\
\hline 39 & Atur Sinaga & 30 & Tiga Ras Kab. Simalungun \\
\hline 40 & Ranto Fajar Siregar & 47 & Simantintulo Kab. Simalungun \\
\hline 41 & Yeni Manik Uluan & 35 & Kab. Simalungun \\
\hline 42 & Niko & 15 & Kab. Simalungun \\
\hline 43 & Doni & 17 & Kab. Simalungun \\
\hline 44 & Febri & 20 & Kab. Simalungun \\
\hline 45 & Maya & 25 & Kab. Simalungun \\
\hline 46 & Riski & 30 & Kab. Simalungun \\
\hline 47 & Fitri Wulandari & 23 & Indra Pura \\
\hline 48 & Obet Hutauruk & 46 & Kec. Harian \\
\hline 49 & Trisman Renol Simarmata & 40 & P. Siantar \\
\hline 50 & Juliana Suraida & 35 & Jln. Puan Gunung Purba Depok \\
\hline 51 & Manan Sitanggang & 25 & P. Siantar \\
\hline 52 & Lusi Nurbayati Sitanggang & 15 & P. Siantar \\
\hline 53 & Lucky Pratama & 20 & P. Siantar \\
\hline 54 & Mei A. Siadani & 25 & P. Siantar \\
\hline 55 & Fery Panggabean & 28 & P. Siantar \\
\hline 56 & Lucky Pratama & 17 & P. Siantar \\
\hline 57 & Joel Manurung & 26 & Bahbirong Kab. Simalungun \\
\hline 58 & Tamara Oktavia & 15 & Pekanbaru \\
\hline
\end{tabular}


Budapest International Research and Critics Institute-Journal (BIRCI-Journal)

Volume 3, No 1, February 2020, Page: 437-451

e-ISSN: 2615-3076(Online), p-ISSN: 2615-1715(Print)

www.bircu-journal.com/index.php/birci emails: birci.journal@gmail.com

\begin{tabular}{|c|c|c|c|}
\hline 59 & Indah Juwita Saragih & 24 & Sidamanik \\
\hline 60 & Edy Subastian & 22 & Indrapura \\
\hline 61 & Very Despian Penggabean & 28 & P. Siantar \\
\hline 62 & Mei Apriana Saragih & 28 & P. Siantar \\
\hline 63 & Irwan Syahputra & 22 & T. Tinggi \\
\hline 64 & Eka Handayani & 19 & Batubara \\
\hline 65 & Ilham Lubis & 25 & Indrapura \\
\hline 66 & Tams Melani & 22 & Tanjungkaso \\
\hline 67 & Ranto Siregar & 27 & Panetonga \\
\hline 68 & Afri Franyoto & 24 & Tiga Balata \\
\hline 69 & Endang Pangestu & 21 & Tiga Balata \\
\hline 70 & Triwulandari & 27 & Kuala Simapang \\
\hline 71 & Diky Wibowo & 24 & Simarimbun \\
\hline 72 & Diky Prayogi & 26 & Sidamanik \\
\hline 73 & Eka Siti Apriyanti & 26 & Sidamanik \\
\hline 74 & Heru Purnomo & 24 & Sidamanik \\
\hline 75 & Bayu Syahputra & 25 & Medan \\
\hline 76 & Kinoy Ajeng Sandi & 22 & Sidamanik \\
\hline 77 & Kriman Reynol Simarmata & 26 & Sinaksak \\
\hline 78 & Juliana Suraida & 27 & Depok \\
\hline 79 & Jonathan Fernano Tp. Bolon & 26 & Tanjung Morawa \\
\hline 80 & Juniko & 22 & Sidamanik \\
\hline 81 & Yeni & 23 & Sidamanik \\
\hline 82 & Riki & 28 & Sidamanik \\
\hline 83 & Dony Septian & 28 & Binjai \\
\hline 84 & Arin & 29 & Binjai \\
\hline 85 & Salama Febriani & 14 & Sidamanik \\
\hline 86 & Maya & 14 & Sidamanik \\
\hline 87 & Wagino & 18 & Sidamanik \\
\hline 88 & Dengot Nainggolan & 30 & Sidamanik \\
\hline 89 & Aknal Tino Kamsa Nainggolan & 10 & Sidamanik \\
\hline 90 & Wira Pradana & 20 & Indrapura \\
\hline 91 & Restu Apriyangga & 24 & Indrapura \\
\hline 92 & Fadly Saputra & 22 & Indrapura \\
\hline 93 & Yanda Aria & 24 & Indrapura \\
\hline 94 & Ali Imron & 21 & Indrapura \\
\hline 95 & Bagas Prama Ananta & 30 & Indrapura \\
\hline 96 & Muh. Nursaid Sinaga & 24 & Medan \\
\hline 97 & Toyan Bakkara & 35 & Sidamanik \\
\hline 98 & Arifin Lubis & 40 & Sidamanik \\
\hline 99 & Dinda Fuji Lestari & 21 & Pem. Bandar \\
\hline 100 & Dimas Afandi & 17 & Pem. Bandar \\
\hline 101 & Mutiara Oktaviani & 17 & Pem. Bandar \\
\hline 102 & Ramansyah & 27 & Karang Sari \\
\hline 103 & Gusti Muliani & 23 & Karang Sari \\
\hline 104 & Rasia Arjuna & 11 & Karang Sari \\
\hline
\end{tabular}


Budapest International Research and Critics Institute-Journal (BIRCI-Journal)

Volume 3, No 1, February 2020, Page: 437-451

e-ISSN: 2615-3076(Online), p-ISSN: 2615-1715(Print)

www.bircu-journal.com/index.php/birci emails: birci.journal@gmail.com

\begin{tabular}{|c|c|c|c|}
\hline 105 & Yudi Samsudin & 30 & Kampar Riau \\
\hline 106 & Sri Wahyuni & 23 & Kampar Riau \\
\hline 107 & Adli Pratama & 25 & Kampar Riau \\
\hline 108 & Noval Ajis Rambe & 19 & Indrapura \\
\hline 109 & Rida Syahfitri & 19 & Batubara \\
\hline 110 & Heriawan & 23 & Batubara \\
\hline 111 & Siti Arbia & 23 & P.Siantar \\
\hline 112 & Alfaruq Siahaan & 23 & P.Siantar \\
\hline 113 & Indah Juwita Saragih & 21 & Sidamanik \\
\hline 114 & May Sri Novi & 30 & Medan \\
\hline 115 & Roy Sirait & 23 & Indrapura \\
\hline 116 & Dedi Suhaini & 19 & Perdagangan \\
\hline 117 & Erwansyah & 20 & Pem. Sidamanik \\
\hline 118 & Kak Wantri Sianipar & 40 & Dibutuon \\
\hline 119 & Sahala Pardamaean & 30 & Raji Nihuta \\
\hline 120 & Ismail Purba Cibru & 20 & Batubara \\
\hline 121 & Muh. Irfan & 39 & Medan \\
\hline 122 & Poltak Sitio & 42 & Medan \\
\hline 123 & Marsinta Pakpahan & 42 & Medan \\
\hline 124 & Berman Sitio & 50 & T. Tinggi \\
\hline 125 & Lamtama Br. Napitupulu & 15 & Pekanbaru \\
\hline 126 & Arif Chandra & 23 & Martubung \\
\hline 127 & Desi Dwi Wahyuni & 22 & Martubung \\
\hline 128 & Nisa Hastari & 19 & Labusel \\
\hline 129 & Ayu Sahfitri & 20 & Labusel \\
\hline 130 & Iwan Sugiarto & 33 & Kampong Musliman \\
\hline 131 & Farida Sarigi Sumbayak & 33 & Kampong Musliman \\
\hline 132 & Wafa Izzy & 7 & Kampong Musliman \\
\hline 133 & Bambang Wardana & 32 & Dolok Melangir \\
\hline 134 & Aska & 6 & Dolok Melangir \\
\hline 135 & Asmi & 2 & Dolok Melangir \\
\hline 136 & Yoka Hendri Sumbayak & 40 & Sidamanik \\
\hline 137 & Manja Naibaho & 35 & Sidamanik \\
\hline 138 & Alfarch & 5 & Sidamanik \\
\hline 139 & Keyla & 2,5 & Sidamanik \\
\hline 140 & Syahputra & 40 & Medan \\
\hline 141 & Awaleni Sumbayak & 35 & Medan \\
\hline 142 & Vikri & 9 & Medan \\
\hline 143 & Husna & 8 & Medan \\
\hline 144 & Bamsyah & 30 & Medan \\
\hline 145 & Nina Insani & 22 & Medan \\
\hline 146 & Naya & 1 & Medan \\
\hline 147 & Sri Hendriyani & 23 & Kota Pinang \\
\hline 148 & Yeni Limbong & 32 & Medan \\
\hline 149 & Beben & 26 & Labusel \\
\hline 150 & Sarsubhan Nasution & 32 & Pem. Karangrejo \\
\hline
\end{tabular}




\begin{tabular}{|l|l|l|l|}
\hline 151 & Atur Duma Sinaga & 19 & Sibunga-bunga \\
\hline 152 & Selmalina Sinaga & 16 & Sibunga-bunga \\
\hline 153 & Halomoan Siagian & 53 & Sibunga-bunga \\
\hline 154 & Halasan Siagian & 40 & Sihemun \\
\hline 155 & Wasinton Silalahi & 46 & Sihemun \\
\hline 156 & Rudiman Siboro & 55 & Panetonga \\
\hline 157 & Elisabet Hutahuruk & 12 & Panetonga \\
\hline 158 & Marsinta Sijabat & 55 & Panetonga \\
\hline 159 & Ipan Rahmat Saputra & 20 & Sei Suka \\
\hline 160 & Ayu Lestari & 19 & Dolok Marawan \\
\hline 161 & Romy Siadari & 17 & Salbe \\
\hline 162 & Dedek Wika Ikani & 23 & Aek Kanopan \\
\hline 163 & Nurwanto & 28 & Kampar Riau \\
\hline 164 & Herman Suryanto & 24 & Aek Nabaraa \\
\hline Total Missing Victims & \multicolumn{2}{|c|}{164 people } \\
\hline
\end{tabular}

Data sources were obtained from Medan SAR Office in 2018

The results of interviews with Iptu Iriani as Panit 2 Unit 5 Sub-Directorate 2 of the North Sumatra Regional Police Directorate General said that there were 164 victims or missing data of 164 (one hundred sixty-four) based on the results of verification by relevant agencies namely Samosir Regional Police, Simalungun Regional Police, Jasa Raharja, Ministry of Transportation UPTD Region II of North Sumatra, Simalungun Regency Government of Social Service Simalungun Regency, Head of Medan SAR Office / SMC which obtained data from the Community Complaints Post located in the tiga Race Simalungun Regency and Simanindo Command Post Samosir Regency and then the number of victims lost was 164 (one hundred sixty four).

The sinking incident of KM. Sinar Bangun, for victims who are compensated for accidents if they have received compensation offered by the shipping party, the peaceful settlement outside the court has been completed. However, if the compensation fund is refused, a compensation claim can be filed.

The claim for compensation that can be submitted is based on Article 40 paragraph (1) of the Shipping Law, which confirms:

Water transport companies are responsible for the safety and security of passengers and/or the goods they transport. These responsibilities may arise as a result of the operation of the ship, in the form of:

1. Death or injury of the passenger carried;

2. Destroyed, lost, or damaged goods transported;

3. Delay in transporting passengers and / or the goods transported; or

4. Third party losses.

Death or injury to a passenger carried is the death or injury of a passenger caused by an accident during transportation and occurs on board, and / or an accident when boarding or getting off the ship, in accordance with statutory regulations. Based on these explanations, as a passenger can be categorized as a passenger who has an accident while in transportation, so it is entitled to accept the responsibility of the ship as the service provider.

The case of KM. Sinar Bangun, compensation is provided in two forms, namely social assistance and social insurance. Social assistance funds come from the state budget and regional budget. Therefore, the amount depends on the government's financial capacity. The 
provision of this assistance was preceded by the determination of the accident as a disaster. There is a separate mechanism regarding designation as a disaster worthy of social assistance with a set of criteria.

Based on Law Number 2 Year 2007 concerning Disaster Management in Article 69 paragraph (1) states that the central and regional governments provide compensation and disability for disaster victims. Further provisions regarding this benefit are regulated according to Government Regulation No. 22/2008 concerning Funding and Management of Disaster Assistance, in particular there are Article 25 and Article 26. Grieving compensation consists of funeral costs and / or condolence money, while disability compensation is given to disabled victims mental and / or physical.

In addition, Law Number 11 Year 2009 concerning Social Welfare and Government Regulation Number 39 Year 2012 concerning the Implementation of Social Welfare, also includes disaster victims as a priority group in providing social protection. This social protection, among others, is provided in the form of direct social assistance in the form of cash through the Ministry of Social Affairs.

Referring to Law Number 2 Year 2007 and Law Number 11 Year 2009, the Ministry of Social Affairs issued Social Minister Regulation (Permenson) Number 1 of 2013 concerning Social Assistance for Disaster Victims. Article 5 of the Permensos mentions several types of direct assistance for victims of disaster, one of them is condolence money and medical expenses. So in the case of KM Sinar Bangun, the Ministry of Social Affairs has decided to provide compensation of Rp 2,500,000 (two million five hundred rupiah) per person for victims while $\mathrm{Rp}$ 15,000,000 (fifteen million rupiah) / death victims.

This social assistance is not specifically for victims of public passenger transportation accidents, but for disaster victims. Distribution of compensation for victims is also just one part of the effort being made. However, because the KM Sinar Bangun accident could be categorized as a disaster, the victims were given compensation.

The compensation for the victims of KM Sinar Bangun also came from the social insurance program based on Law Number 33 of 1964 concerning the Accident Compulsory Accident Coverage Fund. This law regulates the management of special compensation funds for victims of public transportation accidents on land, river or lake, ferries or crossings, sea, and air. Its management uses an insurance mechanism, where funds are collected from passengers through compulsory contributions.

Detailed provisions are regulated in Government Regulation Number 17 of 1965 and Minister of Finance Regulation No.15 / PMK.010 / 2017 related to the amount of compensation and contributions. This fund is managed by BUMN, namely PT Jasa Raharja (Persero). In the context of KM Sinar Bangun, this provision is in line with Law Number 17 of 2008 concerning Shipping and Government Regulation Number 20 of 2010 concerning Transportation on Water. Water transport companies are responsible for the safety and security of their passengers. This responsibility includes the death and injury suffered by the passenger being transported. For this reason, the company is obliged to insure its responsibilities and carry out basic passenger protection insurance in accordance with statutory provisions.

The laws and regulations referred to herein are Law Number 33 of 1964 and its derivative legal products. Law Number 33 of 1964 basically regulates the rights and obligations of passengers. Each accident victim is entitled to compensation in the amount determined by the minister of finance. The Ministry of Finance last year increased the value of compensation by an average of 100\% through PMK No.15 / PMK.010 / 2017, which took 
effect on June 1, 2017. With reference to this PMK, accident victims receive several types of compensation, namely:

1. Death benefit worth IDR 50,000,000 (fifty million) per passenger submitted to the heirs.

2. Permanent notes for a maximum of Rp 50,000,000 (fifty million rupiah). Realization depends on the type of defect calculated based on a certain percentage as stipulated in detail in Government Regulation No. 17 of 1965.

3. For victims who need treatment, receive a maximum maintenance cost of $\mathrm{Rp}$. 20,000,000 (twenty million rupiahs), an ambulance fee of a maximum of Rp. 500 thousand, and first aid costs for accidents a maximum of Rp. 1,000,000.- (one million rupiahs) ).

4. If a passenger dies and does not have an heir, the burial party will be reimbursed for the burial fee of $\operatorname{Rp~4,000,000~(four~million~rupiah).~}$

Mandatory contributions this compensation fund is obtained through mandatory contributions called mandatory fees for ships (IWKL). Each passenger must pay the fees attached to the ticket price. This fee is collected by the transportation owner to be deposited to Jasa Raharja no later than the 27 th of every month. IWKL is divided into two major groups, namely compulsory contributions for public transportation of lakes and rivers and compulsory contributions for public transportation for ferries / crossings and sea.

With reference to PMK No 15 / PMK.010 / 2017, the amount of the mandatory contribution for public transport passengers in lakes and rivers is divided into 2 groups based on ticket prices. For prices up to Rp 2,500, the fee is Rp.100, whereas for ticket prices above Rp. 2,500, the fee is Rp. 200. In the case of KM Sinar Bangun, the contribution fee must be included in the lake and river transportation group.

The important thing to know is that the distribution of compensation follows the principle of no fault. That is, do not consider mistakes made by shipowners. In the case of KM Sinar Bangun there were errors such as the number of passengers that exceeded capacity and did not have manifests. Nevertheless the victims still receive compensation. Because there is no manifest there needs to be a determination of victim data.

Despite using the principle of no fault, law enforcement must still be carried out for violations committed. More importantly, supervision of shipping compliance must be increased. Manifest, for example, is also very much needed in determining the amount of mandatory contributions. Without manifests, determining the amount of mandatory contributions is difficult so there is a chance of data manipulation.

Then, based on an interview with Mrs. Purnama Sidahuruk, one of the wives of the victims sinking of KM. Sinar Bangun in the waters of Toba Lake where her husband was not found or declared missing said that the protection provided was only insurance assistance from PT. Jasa Raharja (Persero) Medan North Sumatra Province Branch each heir received Rp. 50,000,000 (fifty million rupiah). In addition, there are also some assistance provided by the government, among others: Social Service Rp. 15,000,000 (fifteen million rupiah), the Government of Samosir Regency in the amount of Rp. 20,000,000 (twenty million rupiah), the Government of Simalungun Regency in the amount of Rp. 2,000,000 (two million rupiah) and rice, sugar and cooking oil assistance. (Results of an interview with Ms. Purnama Br. Sidahuruk on November 31, 2019) 


\section{Conclusion}

The form of legal protection given to the victims sinking of KM. Sinar Bangun in Toba Lake is that every accident victim is entitled to protection based on the provisions of the legislation, which is provided by the government in the form of direct social assistance in the form of cash through the Ministry of Social Affairs, types of compensation for victims in the form of death compensation, permanent disability compensation, and survivors. Each accident victim also received compensation from PT Jasa Raharja (Persero), the amount of which was determined by the miniser of finance, in addition to other legal protections the implementation of legal proceedings for the occurrence of criminal acts.

\section{References}

Amaruddin, Zainal Asikin. 2010. Pengantar Metode Penelitian Hukum. Jakarta: Rajawali Pers.

Arief Amrullah, 2015, Politik Hukum Pidana Perlindungan Korban Kejahatan Ekonomi di Bidang Perbankan Dalam Perspektif Bank Sebagai Pelaku (Offender), Yogyakarta: Genta Publishing.

Ahmad Sofian, 2018, Ajaran Kausalitas Hukum Pidana, Jakarta: Kencana

Chairul Huda, 2006, Dari Tiada 'Pidana Tanpa Kesalahan' Menuju Kepada 'Tiada Pertanggungjawaban Pidana Tanpa Kesalahan'. Jakarta: Kencana.

Chazawi, Adami. 2018. Pelajaran Hukum Pidana Bagian 1. Jakarta : PT Raja Grafindo Persada

Gultom, Maidin. 2012. Perlindungan Hukum terhadap Anak dan Perempuan, Bandung: Refika Aditama.

Hamzah, Jur Andi. 2012. Asas-Asas Hukum Pidana di Indonesia \& Perkembangannya. Jakarta : P.T. Sofmedia

Hari Utomo, (2017), Siapa Yang Bertanggung Jawab Menurut Hukum Dalam Kecelakaan Kapal ( Legally Responsible Parties In Ship Accident ), Jurnal Legislasi Indonesia, 14 (1): 59-60

I Agusti Agung Dian Bimantara dan I Putu Sudarma Sumadi, (2018), Konsep Restitusi Terhadap Perlindungan Korban Tindak Pidana di Indonesia, Kertha Wicara, 7 (2): 3-4

Kusumohamidjojo, Budiono. 1999.Ketertiban yang Adil. Jakarta: Grasindo.

Ketut Adi Wirawan, (2015), Perlindungan Terhadap Korban Sebagai Penyeimbang Asas Legalitas, Jurnal Advokasi, 5 (2): 173

Moeljatno. 2008. Asas-Asas Hukum Pidana. Jakarta: Rineka Cipta

Moleong, Lexy, 2006, Metodologi Penelitian Kualitatif. Bandung: Remaja Rosda Karya.

Mertokusumo, Sudikno, A. Pitlo, 1993, Penemuan Hukum, Yogyakarta: Citra Aditya Bakti.

Mertokusumo, Sudikno. 2003. Mengenal Hukum Suatu Pengantar. Yogyakarta: Liberty

Maya Indah, 2014, Perlindungan Korban Suatu Perspektif Victimiogi dan Kriminologi, Jakarta: Sinar Grafika.

Nasution, S., 2007, Metode Research (Penelitian Ilmiah), Bumi Aksara, Jakarta.

Peraturan Pemerintah Nomor 22 Tahun 2008 tentang Pendanaan dan Pengelolaan Bantuan Bencana

Peraturan Pemerintah Nomor 2 Tahun 2002 tentang Tata Cara Perlindungan terhadap Korban dan saksi dalam Pelanggaran Hak Asasi Manusia 
Prodjohamidjojo, Martiman. 2001.Penerapan Pembuktian Terbalik Dalam Kasus Korupsi. Bandung: Mandar Maju.

Raharjo, Satjipto, 2000, Ilmu Hukum, Bandung: PT. Citra Aditya

Renggong, Ruslan. 2016. Hukum Pidana Khusus. Jakarta : Prenadamedia Group

Teguh Prasetyo, Abdul Halim Barkatullah, 2005, Politik Hukum Pidana Kajian Kebijakan Kriminalisasi dan Dekriminalisasi, Yogyakarta: Pustaka Pelajar

Undang-Undang Nomor 31 Tahun 2014 Perubahan Atas Undang-Undang Nomor 13 tahun 2006 tentang Perlindungan Saksi dan Korban

Undang-Undang Nomor 17 Tahun 2008 tentang Pelayaran

Undang-Undang Nomor 27 Tahun 2004 tentang Komisi Kebenaran dan Rekonsiliasi

Undang-Undang Nomor 2 Tahun 2007 tentang Penanggulangan Bencana

Yulia, Rena. 2010. Viktimologi Perlindungan Hukum terhadap Korban Kejahatan. Yogyakarta : Graha Ilmu

Yuliana Beatrich Udam, (2013), Perlindungan Hukum Bagi Konsumen Pemakai Jasa Angkutan Laut di Pelabuhan Jayapura, Mix Law: Journal of Law, 1 (1): 104 